\title{
Social Status of Conjugal Womanhood: A study with the Irula Tribe at Kunjapannai, NilgrisRegion
}

\author{
Emmanuel D. *, Dr. Rajan** \\ ${ }^{1}$ Ph. D. Scholar, ${ }^{2}$ Associate Prof. \&Head,Dept. of Social Work WorkPSG College of Arts \& Science
}

\begin{abstract}
Social status is a standing or a scrupulousness which is given to personages in the society. Social status can be seen in two dimensions namely through achieved status and ascribed status. Achieved status can be earned through the triumphs, success, achievements of each individual. Whereas ascribed status is earned from the birth of an individual. Wealth, family status, popularity of the family, etc. are few influences which add credits to it. Social status in India varies from individuals to individuals, place to place, male to female, etc.

In earlier day women were considered as a weaker sex in all aspects. The status of women in India has taken a different shape in the contemporary era. There are many women playing an important role in different sectors like politics, business, education, bank, IT, etc. However women in India continue to face many problems and social challenges. So this study throws light to bring out the level of social status among conjugal womanhood of Irula tribe.
\end{abstract}

Key words-Status, Married Women

\section{Introduction}

Social status is a basic identity of how much powerful an individual is in a society. In numerous places social status is diligently connected with ethics, use of prosperity, etc. The word status entails communal stratification on an upright measure. All civilizations have established a collective stratification inside their inhabitants were personages are credited a firm status with their social grading.

The status of women in India has changed a lot from the past times. In ancient times, women were treated almost equal to the men folk. But in the medieval times things weren't in favor of the womenfolk. So the men were in hype dominating the womenfolk. Sati, Jauhar, Devadasis, etc. were few practices which were pulling women down in the society. But now in this contemporary era, after many struggles women have proved themselves equal to men in all the sectors. In India women have started playing important roles in different sectors like politics, hospitals, education, IT, business, etc.

During British rule in India, many European Scholars came down to India to study about the tribal people and the problems faced by the women. The Europeans felt that women were ill-treated in the society. Few people like Martha Mault nee Mead, Eliza Caldwell, and Sir. Rev. Dr. William Carey sacrificed their life for the upliftment of the women folk in India. Even today in some places like slums, villages, tribal areas the women are not treated as like men. So the women folks are not able to expand their boundaries and get an upswing in life.

\section{Irula Tribe - A brief outlook}

Irulas are one among the six primitive tribal groups in Tamil Nadu. The name Irulas are derived from the tamil word 'Irul' meaning dark which refers to their skin tone. In Nilgris region, Irulas are well spread in four taluks namely Ooty, Conoor, Kotagiri and Kundah. Irula people have their own language which is again called as "Irula". This language is a mix of Tamil and Malayalam and it has its own dialect. Basically Irula people are non-vegetarians. They follow cross cousin marriage system among themselves. Also child marriages are very common among them. In earlier days they were snake and rat hunters. But now they involve in tea estate work and other kooli works.

Irula people mostly live in joint family system. The literacy rate among Irula people is just $34.30 \%$. Now they are a little aware of education schemes which are given to children through various schemes. Women are given opportunities in the panchayat elections and to take part in temple committees. Irula again are divided into different sub groups such as Kasabas, Mudumars and Uraliirulas. Irulas being classified in hindu religion, they do noy burn the dead people. They bury their dead in a seated posture. Each grave is demarcated by an earth mound.

Now in modern times, SHG are plenty in numbers which ensures development. Many children from Irula tribe do their college education in Coimbatore. Both men and women go for work in the day time to 
increase the revenue in their family. There is no child labor and dowry system. Men are a little addicted to the tobacco practices and liquors.

\section{Review of Literature}

Francis Buchanan (1800) conducted a study on "NilgrisIrulas". This study tes us about their accommodation patterns and their living style. In earlier days Irulas used to live in nuclear settlements. Many houses were built near the courtyard. Their houses will be mostly built with the ingredient of bamboos.

Haimendorf (1943) conducted a study on Husband and Wife in Irulas. This study tells Husband and Wife in the tribal area live as practical purpose partners with equal rights. Their properties are jointly owned. The man can enjoy all the benefits other than the personal belongings of the wife which was given by her parents.

YogeshAtal (1985) conducted a study "Women in tribal areas". This study tells that women have their choice in selecting their partner for life. Widow Remarriage, dissolution of marriage everything is even present among this tribe.

\section{Research Methodology Goals of the Study}

1. To study the socio- demographic details of married women in Irula Tribe at Kunjapannai.

2. To study the social status of married women in the Irula community.

3. To assess the various factors those are responsible for the development of Irula women and to facilitate new strategies for their empowerment.

\section{Study Strategy}

The researcher applied descriptive study plan. The descriptive study design suits this study as the researcher has tried to label only the social status of married women in the Irula community at Kunjapannai

\section{Hypothesis}

- Age might influence the social status of the married women

- Monthly income might influence the social status of the married women

- Level of Education might influence the social status of the married women

\section{Universe and Sampling}

The Irula people who are living in Kunjapannai are 321. The Scholar selected 60 respondents by using purposive sampling technique.

\section{Tools of Facts gathering}

The Researcher used discussion schedule to collect data from Kunjapannaiplace for the study.

\section{ANALYSIS AND INTERPRETATION}

\section{Distribution of respondents on the basis of their Age}

\begin{tabular}{|l|c|c|}
\hline \multicolumn{1}{|c|}{ Age } & Frequency & Percentage \\
\hline Less than 30 & 12 & 20 \\
\hline $31-40$ & 20 & 33.4 \\
\hline $41-50$ & 14 & 23.3 \\
\hline 51 \& above & 14 & 23.3 \\
\hline Total & 60 & 100 \\
\hline
\end{tabular}

Among 60 respondents majority of the respondents $33.4 \%$ (20) belong to the age group of $31-40,23.3 \%$ (14) belong to the age group of $41-50 \& 51$ above, $23.3 \%$ (14) belong to the age group of $51 \&$ above. $20 \%$ (12) belong to the age group of less than 30 .

Distribution of respondents on the basis of No. of children

\begin{tabular}{|l|l|l|}
\hline No. of Children & Frequency & Percentage \\
\hline Less than 2 & 34 & 56.7 \\
\hline 3 or 4 & 14 & 23.3 \\
\hline More than 5 & 12 & 20 \\
\hline Total & 60 & 100 \\
\hline
\end{tabular}


Social Status of Conjugal Womanhood: A study with the Irula Tribe at Kunjapannai, NilgrisRegion

Among 60 respondents $56.7 \%$ (34) respondents have children less than 2, 23.3\% (14) respondents have 3 or 4 children, 20\% (12) respondents have more than 5 children.

Distribution of respondents on the basis of their family type

\begin{tabular}{|l|l|l|}
\hline Type of family & Frequency & Percentage \\
\hline Joint & 48 & 80 \\
\hline Nuclear & 12 & 20 \\
\hline Total & 60 & 100 \\
\hline
\end{tabular}

Among 60 respondents $80 \%$ (48) respondents live in a joint family type, 20\% (12) respondents live in a nuclear family type.

Distribution of respondents on the basis of their members in monthly income of family

\begin{tabular}{|l|l|l|}
\hline Income (p.m.) & Frequency & Percentage \\
\hline 1 (Less than 1000) & 24 & 40 \\
\hline $2(1001-2000)$ & 14 & 23.3 \\
\hline $3(2001 \&$ above) & 22 & 36.7 \\
\hline Total & 60 & 100 \\
\hline
\end{tabular}

Among 60 respondents $40 \%$ (24) respondent's earn less than 1000 Rs. p.m., $36.7 \%$ (22) respondent's earnmore than 2001 p.m., $23.3 \%$ (14) respondent's earn between 1001- 2000 Rs. p.m.

Distribution of respondents on the basis of their education level

\begin{tabular}{|l|l|l|}
\hline Income $($ p.. . $)$ & Frequency & Percentage \\
\hline 1 (below $5^{\text {th }}$ Grade) & 20 & 33.3 \\
\hline $2\left(6^{\text {th }}-10^{\text {th }}\right.$ Grade $)$ & 28 & 46.7 \\
\hline $3\left(10^{\text {th }}\right.$ \& above $)$ & 12 & 20 \\
\hline Total & 60 & 100 \\
\hline
\end{tabular}

Among 60 respondents $46.7 \%$ (28) respondentshave studied between $6^{\text {th }}-10^{\text {th }}$ grades, $33.3 \%$ (20) respondent's earn have studied below $5^{\text {th }}$ grade, $20 \%(12)$ respondentshave studied more than $10^{\text {th }}$ grades.

Distribution of respondents on the basis of their Social Status

\begin{tabular}{|c|c|c|}
\hline Social Status & Frequency & Percentage \\
\hline Less & 28 & 46.7 \\
\hline Moderate & 10 & 16.7 \\
\hline High & 22 & 36.7 \\
\hline Total & 60 & 100 \\
\hline
\end{tabular}

Among 60 respondents $46.7 \%$ (28) respondents have less social status, $36.7 \%$ (22) respondents have more social status, and $16.7 \%$ (10) respondents have moderate level of social status.

Association between Age and Social Status

\begin{tabular}{|c|l|l|l|l|}
\hline Age & $\begin{array}{l}\text { Low Social Status } \\
(<30)\end{array}$ & $\begin{array}{l}\text { Moderate Social } \\
\text { Status } \\
(\mathbf{3 1 - 3 2})\end{array}$ & $\begin{array}{l}\text { High Social Status } \\
(\mathbf{3 3}>\mathbf{)}\end{array}$ & Total \\
\hline Less than 30 & $6(50 \%)$ & $2(16.7 \%)$ & $4(33.3 \%)$ & 12 \\
\hline $31-40$ & $14(70.0 \%)$ & $0(0 \%)$ & $6(30 \%)$ & 20 \\
\hline $41-50$ & $4(28.6 \%)$ & $4(28.6 \%)$ & $6(42.9 \%)$ & 14 \\
\hline $51 \&$ above & $4(28.6 \%)$ & $4(28.6 \%)$ & $6(42.9 \%)$ & 14 \\
\hline Total & 28 & 10 & 22 & 60 \\
\hline
\end{tabular}

Calculated Value $=10.612 \mathrm{df}=6$

Chi square test was applied to find out the association between age and social status. It is proved that there is no significant association between age and social status. 
Social Status of Conjugal Womanhood: A study with the Irula Tribe at Kunjapannai, NilgrisRegion

Association between Monthly Income and Social Status

\begin{tabular}{|l|l|l|l|l|}
\hline Monthly Income & $\begin{array}{l}\text { Low Social Status } \\
(<30)\end{array}$ & $\begin{array}{l}\text { Moderate Social } \\
\text { Status } \\
(\mathbf{3 1 - 3 2})\end{array}$ & $\begin{array}{l}\text { High Social Status } \\
(\mathbf{3 3}>)\end{array}$ & Total \\
\hline$<1000$ & $12(50 \%)$ & $4(16.7 \%)$ & $8(33.3 \%)$ & 24 \\
\hline $1001-2000$ & $8(57.1 \%)$ & $2(14.3 \%)$ & $4(28.6 \%)$ & 14 \\
\hline $2001 \&$ Above & $8(36.4 \%)$ & $4(18.2 \%)$ & $10(45.5 \%)$ & 22 \\
\hline Total & 28 & 10 & 22 & 60 \\
\hline
\end{tabular}

Calculated Value $=1.751 \mathrm{df}=4$

Chi square test was applied to find out the association between monthly income and social status. It is proved that there is no significant association between monthly income and social status.

Association between Education level and Social Status
\begin{tabular}{|l|l|l|l|l|}
\hline Education Level & $\begin{array}{l}\text { Low Social Status } \\
(<30)\end{array}$ & $\begin{array}{l}\text { Moderate Social } \\
\text { Status } \\
(\mathbf{3 1 - 3 2})\end{array}$ & $\begin{array}{l}\text { High Social Status } \\
(\mathbf{3 3}>)\end{array}$ & Total \\
\hline Below $5^{\text {th }}$ grade & $10(50 \%)$ & $6(30 \%)$ & $4(20 \%)$ & 20 \\
\hline $6^{\text {th }}-10^{\text {th }}$ grade & $12(42.9 \%)$ & $4(14.2 \%)$ & $12(42.9 \%)$ & 28 \\
\hline Above $10^{\text {th }}$ grade & $6(50 \%)$ & $0(0 \%)$ & $6(50 \%)$ & 12 \\
\hline Total & 28 & 10 & 22 & 60 \\
\hline
\end{tabular}

Calculated Value $=6.781 \mathrm{df}=4$

Chi square test was applied to find out the association between the level of education and social status. It is proved that there is no significant association between the level of education and social status.

\section{MAJOR FINDINGS}

- Among 60 respondents $46.7 \%$ (28) respondents have less social status, $36.7 \%$ (22) respondents have more social status, and $16.7 \%$ (10) respondents have moderate level of social status.

- There is no significant difference between the age and social status.

- There is no significant difference between educational level and social status.

- There is no significantdifference between the monthly income of the married women and their social status.

\section{Conclusion}

The status of women in contemporary India occupies an important place and her role that she plays especially to uplift her family is really extraordinary. The removal of inequality in the society has brought in many changes in the lives of people as well asit has brought in some meaning in lives of men folks. But this level of status does not exist in all the parts of India. It defers from urban to rural, rural to slums and slums to tribal areas.

Compared to other tribal people in Nilgris, Irula are much better in their educational level. But the literacy rate is just $34.30 \%$ only. This plays a very important role in lives of women. Illiteracy has been a stumbling block for the women of Irulaand it decreases the social status of women folk among themselves. Even though most of the Irula women folk are married the respect which the society gives for them is not upto the mark. The correlation test reveals us that there is an association between the monthly income of the married women and their social status. But still many women are not given the same privileges unlike men.

Usually the social status is associated with the class, wealth, life style and caste. Irula women are basically poor in class and wealth and their lifestyle is not rich. This is one among the reason that they don't get a respectable social status within and outside their place. SHGs are working very hard to bring in decent revenue and to make up the fallen status. It is just like a farmer waiting for the precious fruit of the earth until it receives the rain. 


\section{PHOTOS}

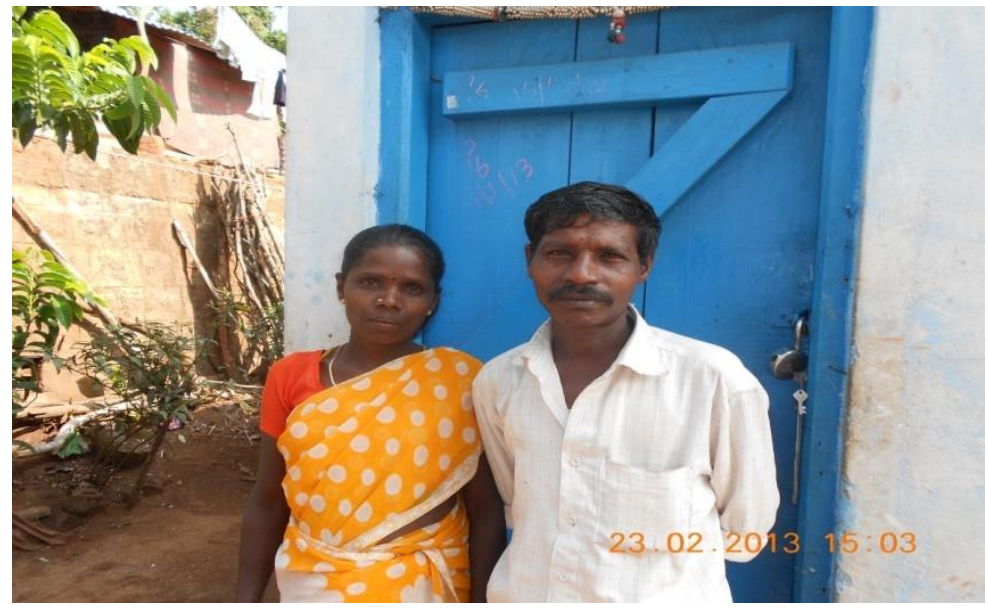

An Irula Couple

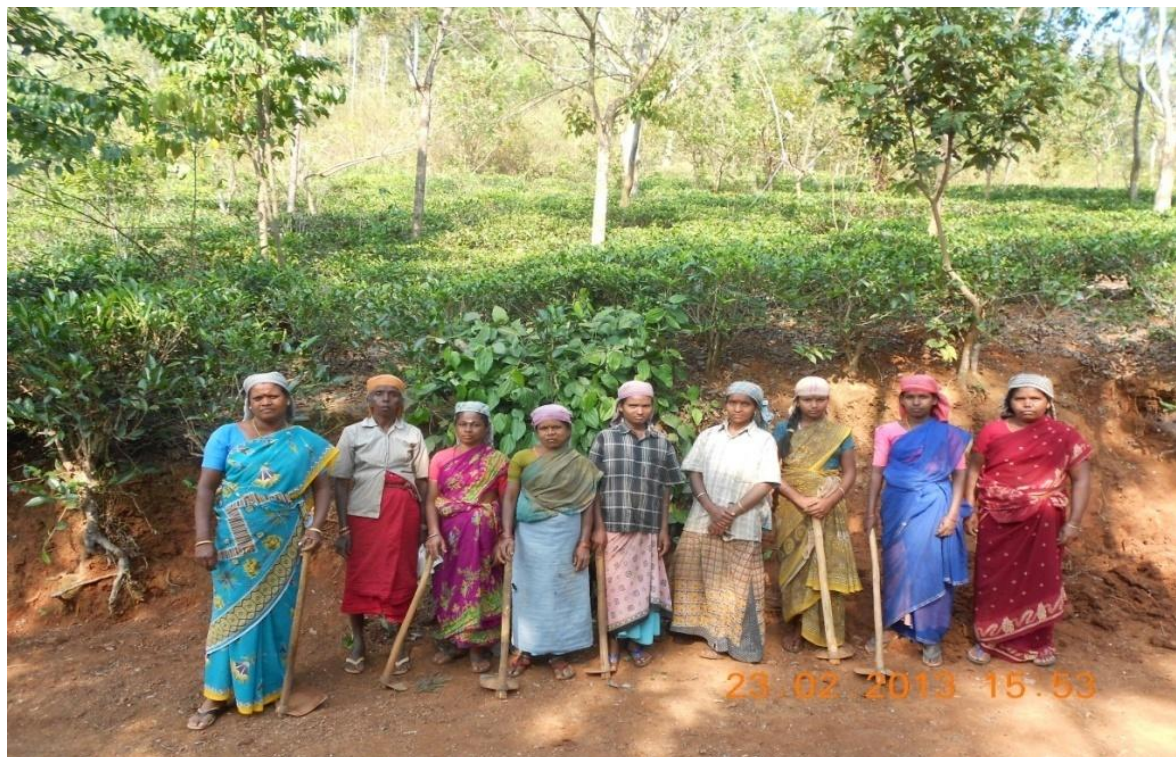

Some Married Women of Irula at their workspot

Bibliography

- HaratioBIckerstatteRowney(1882) The Ild Tribes of India, B.R. Publishing Corporation, New Delhi, India

- C.P. Bhatnagar (1971) The Crisis in Indian Society, National Publishing house, New Delhi, India.

- N.S. Krishna Kumari (1987), Status of Women in India Uppal Publishing house, New Delhi, India.

- B.Bhandari (1989) Tribal marriages \& Sex relations, Himanshu Publications, Udaipur, India.

- Uma Shankar Jha, Arati Mehta, LatikaMenon (1998), Status of Indian Women, Kaninhka Publishers, New Delhi, India.

- Laura Kramer (2001) The Sociology of Gender- A Brief Introduction, Rawat Publications, New Delhi, India

- Shweta Prasad (2011) Women in India- Trails \&Trimphs, VinodVasishtha for Viva Books Pvt. Ltd., New Delhi, India. 